DOI: https://doi.org/10.31933/dijms.v2i1

Received: 23 July 2020, Revised: 17 August 2020, Publish: 14 October 2020

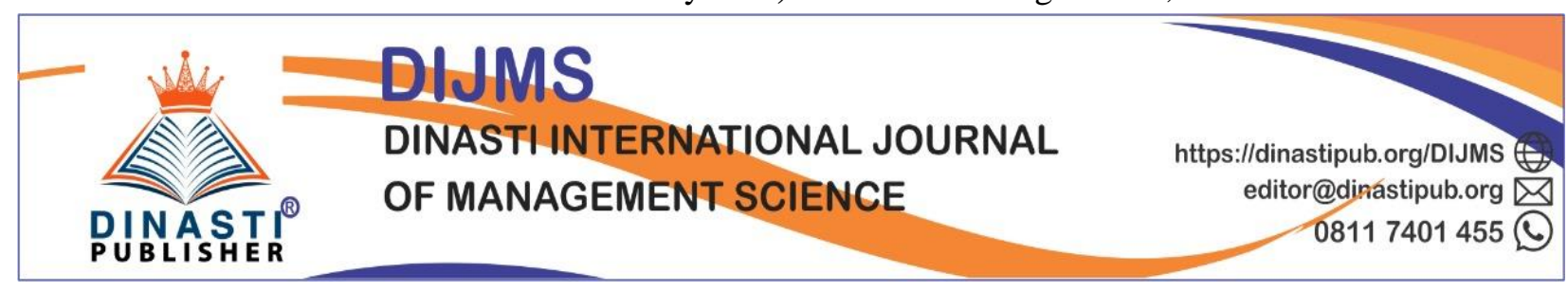

\title{
REACTION OVER EMPLOYEES TURNOVER INTENTION WHICH INFLUENCED BY CAREER DEVELOPMENT, WORK LOAD AND COMPENSATION AT PT XYZ
}

\author{
Rongguan Selamat Tiopan Silitonga ${ }^{1}$, Irfan Noviandy Aulia ${ }^{2}$ \\ 1) Master of Management in Mercu Buana University, Jakarta, Indonesia, guan.silitonga@ gmail.com \\ 2) Lecturer of Postgraduate in Mercu Buana University, Jakarta, Indonesia, \\ irfan.noviandy@mercubuana.ac.id
}

\section{Corresponding Author: First Author}

Abstract: This research intend to examined that influence which came from career development, workload and compensation towards turnover intention at PT XYZ's employees. Research population were employees from PT XYZ JATA 2 Area, which amounting to 378 employees, which sample amounted to 195 respondents (by Slovin 5\% error tolerance). Data analysis method by multiple linear regression analysis to examined several hypothesis. Those results that earned from this research, such as : 1) There had strongly influence between career development to turnover intention; 2) There has none reaction which occurs from workload towards turnover intention; 3) There had no impact between compensation and turnover intention; 4) There had simultaneously reacted between career development, workload, and compensation against turnover intention.

Keywords: Career development, workload, compensation, turnover intention.

\section{INTRODUCTION}

One of human resources problem which related to labor in company regarding employee turnover intention. Turnover intention is desires from employees to quit their jobs and has an impact to company that should need faced with decreasing employee in row and high costs which incurred to recruit and train new employees

PT. XYZ is a subsidiary under ASTRA International which engaged to consumer finance business that located in South Jakarta This company has similiar problem about employee turnover intentions every month. It could be seen that turnover in these companies has increased from year to year. In 2016 these average turnover at PT. XYZ around 1.18\%, then rose by $0.31 \%$ to $1.49 \%$ in 2017 , and in 2018 it has increased again by $0.03 \%$ from prior year to $1.52 \%$. 


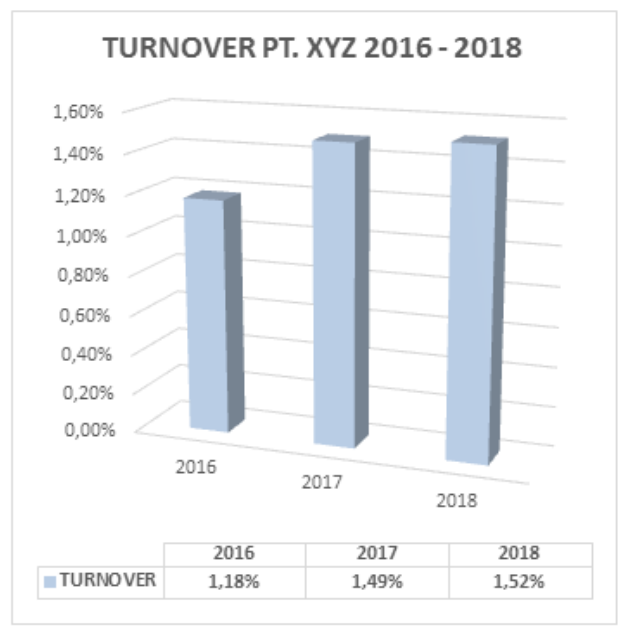

Figure 1. PT XYZ Turnover Percentage Graph during period of 2016-2018

An increase over employee turnover Has become concern to company Therefore interviews were conducted to find out those matters Which has an affect to employees so they Would leave company through Exit interview system. According to exit interview result, it could be seen that $55.74 \%$ felt that there was an Work overload which assigned to them, $34.99 \%$ felt that compensation received was inadequate and $75.18 \%$ from outstanding employees that decide to opted out which indicated that company's lack of care towards career development and its employees.

Table 1. PT XYZ Exit Interview Data

\begin{tabular}{|c|c|c|c|c|}
\hline Factors That Cause Turnover & 2016 & 2017 & 2018 & Average \\
\hline \multicolumn{5}{|l|}{ Career Development } \\
\hline Outstanding employees that exit & $74.07 \%$ & $74.46 \%$ & $77.01 \%$ & $75.18 \%$ \\
\hline Non-performance empl oyees who leave & $25.93 \%$ & $25.54 \%$ & $22.99 \%$ & $24.82 \%$ \\
\hline \multicolumn{5}{|l|}{ Workload } \\
\hline Overload & $43.54 \%$ & $44.39 \%$ & $44.84 \%$ & $44.26 \%$ \\
\hline Not overload & $56.46 \%$ & $55.61 \%$ & $55.16 \%$ & $55.74 \%$ \\
\hline \multicolumn{5}{|l|}{ Relationship with Colleagues } \\
\hline Good and smooth & $84.08 \%$ & $85.81 \%$ & $86.70 \%$ & $85.53 \%$ \\
\hline Not good and there has obstacles & $15.92 \%$ & $14.19 \%$ & $13.30 \%$ & $14.47 \%$ \\
\hline \multicolumn{5}{|l|}{ Relationship with Colleagues } \\
\hline Good and smooth & $71.88 \%$ & $75.19 \%$ & $77.64 \%$ & $74.90 \%$ \\
\hline Not good and there has obstacles & $28.12 \%$ & $24.81 \%$ & $22.36 \%$ & $25.10 \%$ \\
\hline \multicolumn{5}{|l|}{ Communication } \\
\hline Good and smooth & $80.47 \%$ & $84.03 \%$ & $85.25 \%$ & $83.25 \%$ \\
\hline Not good and one way & $19.53 \%$ & $15.97 \%$ & $14.75 \%$ & $16.75 \%$ \\
\hline \multicolumn{5}{|l|}{ Facilities and Welfare } \\
\hline Satisfying & $82.71 \%$ & $80.58 \%$ & $82.42 \%$ & $81.91 \%$ \\
\hline Less satisfactory & $17.29 \%$ & $19.42 \%$ & $17.58 \%$ & $18.09 \%$ \\
\hline \multicolumn{5}{|l|}{ Work Support Equipment } \\
\hline Adequate & $88.29 \%$ & $88.65 \%$ & $88.27 \%$ & $88.40 \%$ \\
\hline Inadequate & $11.71 \%$ & $11.35 \%$ & $11.73 \%$ & $11.60 \%$ \\
\hline \multicolumn{5}{|l|}{ Workspace } \\
\hline Qualify & $80.03 \%$ & $81.56 \%$ & $80.93 \%$ & $80.84 \%$ \\
\hline Not qualify & $19.97 \%$ & $18.44 \%$ & $19.07 \%$ & $19.16 \%$ \\
\hline \multicolumn{5}{|l|}{ Compensation } \\
\hline Adequate & $66.19 \%$ & $63.68 \%$ & $65.16 \%$ & $65.01 \%$ \\
\hline Inadequate & $33.81 \%$ & $36.32 \%$ & $34.84 \%$ & $34.99 \%$ \\
\hline
\end{tabular}

Similiar to prior exit interview data, pre-survey result from 25 employees showed that $72 \%$ that they had not been promoted for more than 3 years, though as many as $60 \%$ said 
that they had exceed performance at company. Those also could be seen from the pre-survey result to employees about workloads, whereas $84 \%$ feel burdened by their work. Likewise occur to pre-survey result that related to compensation which given to employees showed that as many as $64 \%$ were not satisfied with compensation which provided.

According to those phenomenon of pre-survey result that accomplished at PT. XYZ and also PT. XYZ's turnover data during these period 2016 to 2018, Researchers was eager to evaluated these matter regarding employee turnover intentions at PT. XYZ with title "Reaction over Employees Turnover intention which influenced by Career Development , Work load and Compensation at PT XYZ".

\section{LITERATURE REVIEW}

\section{Career Development}

Career development is company or organization program in order to provide training and opportunities to improve expertise and also reach higher position in a company or organization. Sunyoto (2012: 166) added that there has two dimensions to illustrated about career development in companies, which is career planning and career management.

\section{Workload}

Workload is quantity of work done by a person related to his/ her works within a certain time period based on responsibilities that given from organization or company.

\section{Compensation}

According to Milkovich and Newman in Runkat and Aulia (2019) compensation is all forms of financial rewards and measured services and benefits received by employees as part of work relationship.

\section{Turnover Intention}

Turnover intention is desire or intention on employee to leave company and get a better job from current job. Dimensions from turnover intention according to Mobley in Mahdi, et., Al. (2012) were consists of thinking of quitting, intent to search, and intent to quit.

\section{Theoretical Framework}

According to background from theory research above, these following theoretical framework could be made as its follows: 


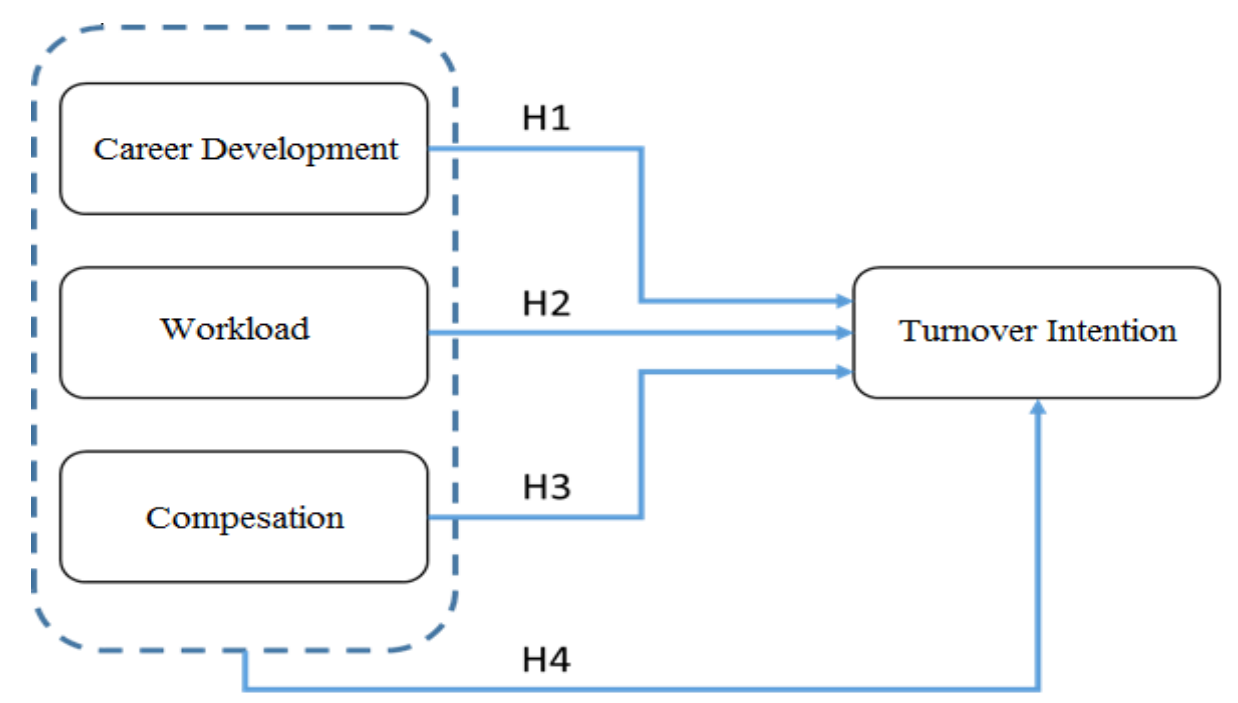

Figure 2. Theoretical Framework

\section{Hypothesis}

These several hypothesis from this reseach, namely 1) Career development had strong impact towards turnover intention; 2) Workload had significant reaction over turnover intention; 3) Compensation had huge effect to turnover intention; and 4) Career development, workload, and compensation together had remarkable affects on turnover intention.

\section{RESEARCH METHODS}

This type of research used quantitative research by causal descriptive approach to describe those connection between variables which studied. Independent variable in this research were consisted from career development, workload and compensation, while dependent variable was turnover intention. Population research were employees of PT. XYZ Area JATA 2 in South Jakarta, which amounted 378 employees. Discovered from sample size to be taken from research used Slovin formula with an error tolerance level of 5\% so these sample of 195 respondents was obtained. Determination from respondents was selected by using non-probability sampling techniques with accidental sampling method. Data collection methods used collecting library research and field research. Data analysis method that used in this research was multiple linear regression analysis through validity, reliability, classic assumption and hypothesis examination by SPSS 25 program.

\section{RESULT AND DISCUSSION Validity and Reliability Test}

According to validity test result, it could be seen that all indicator items on research variables have value of $r$ count $>r$ table $(0.138)$, so it could be said that all items from these research indicator were valid. 
Table 2. Validity Test Results

\begin{tabular}{ccccccccccccc}
\hline No. & $\mathbf{r}_{\text {count }} \mathbf{X}_{\mathbf{1}}$ & $\mathbf{r}_{\text {table }}$ & Info & $\mathbf{r}_{\text {coumt }} \mathbf{X}_{\mathbf{2}}$ & $\mathbf{r}_{\text {table }}$ & Info & $\mathbf{r}_{\text {coumt }} \mathbf{X}_{\mathbf{3}}$ & $\mathbf{r}_{\text {table }}$ & Info & $\mathbf{r}_{\text {count }} \mathbf{Y}$ & $\mathbf{r}_{\text {table }}$ & Info \\
\hline 1 & 0.711 & 0.138 & Valid & 0.605 & 0.138 & Valid & 0.783 & 0.138 & Valid & 0.706 & 0.138 & Valid \\
2 & 0.231 & 0.138 & Valid & 0.433 & 0.138 & Valid & 0.769 & 0.138 & Valid & 0.833 & 0.138 & Valid \\
3 & 0.807 & 0.138 & Valid & 0.451 & 0.138 & Valid & 0.811 & 0.138 & Valid & 0.829 & 0.138 & Valid \\
4 & 0.494 & 0.138 & Valid & 0.773 & 0.138 & Valid & 0.654 & 0.138 & Valid & 0.859 & 0.138 & Valid \\
5 & & & & 0.728 & 0.138 & Valid & 0.238 & 0.138 & Valid & & 0.138 & \\
6 & & & & 0.712 & 0.138 & Valid & 0.762 & 0.138 & Valid & & 0.138 & \\
7 & & & & & & & 0.836 & 0.138 & Valid & & 0.138 & \\
8 & & & & & & & 0.800 & 0.138 & Valid & & 0.138 & \\
\hline
\end{tabular}

Based on reliability test result, it could be seen that Cronbach's Alpha career development, workload, compensation and turnover intention had greater value than specified conditions (0.6), then it could be concluded that all research variables were declared reliable.

Table 3. Reliability Test Results

\begin{tabular}{cccc}
\hline Variable & Cronbach's Alpha & Terms & Info \\
\hline Career Development & 0.746 & $>0.6$ & Reliable \\
Workload & 0.669 & $>0.6$ & Reliable \\
Compensation & 0.869 & $>0.6$ & Reliable \\
Turnover Intention & 0.821 & $>0.6$ & Reliable \\
\hline
\end{tabular}

\section{Classic Assumption Test}

According to normality test result by Kolmogorov-Smirnov One-Sample Test, it could be seen that these Asymp value. Sig (2-tailed) is 0.27 (27\%) meaning it was greater than $0.05(5 \%)$ as normally distributed from research data determination.

Table 4. Normality Test Results

\begin{tabular}{llr} 
& & $\begin{array}{r}\text { Unstandardized } \\
\text { Residual }\end{array}$ \\
\hline N & Mean & 195 \\
\hline Normal Parameters & Std. Deviation & 0,0000000 \\
\hline Most Extreme Differences & Absolute & 3,60481131 \\
\hline & Positive & 0,068 \\
\hline Test Statistic & Negative & 0,068 \\
\hline Asymp. Sig. (2-tailed) & & $-0,037$ \\
\hline $\begin{array}{l}\text { a. Test distributionis Normal. } \\
\text { b. Calculated from data. }\end{array}$ & 0,068 \\
\hline c. Lilliefors Significance Correction. & $.027^{\circ}$ \\
\hline
\end{tabular}

Based on multicollinearity test results, it could be seen that VIF value for each independent variable has less than 10 with tolerance value is more than 0.1 , so it could be stated that this regression model is free from multicollinearity. 
Table 5. Multicollinearity Test Results

\begin{tabular}{ll|r|r} 
Model & \multicolumn{2}{|c}{$\begin{array}{c}\text { Collinearity Statistics } \\
\text { Tolerance }\end{array}$} & \multicolumn{1}{c}{ VIF } \\
\hline 1 & (Constant) & & \\
\cline { 2 - 3 } & Carrer Development & 0,707 & 1,414 \\
\cline { 2 - 3 } & Workload & 0,970 & 1,031 \\
\cline { 2 - 3 } & Compensation & 0,724 & 1,381 \\
\hline
\end{tabular}

a. Dependent Variable: TURNOVER INTENTION

According to heteroscedasticity test result by scatterplot test, it could be seen that those points spread with unclear patterns above and below number 0 on $\mathrm{Y}$ axis. These results was indicated that there has no heteroscedasticity problem occur on this research model.

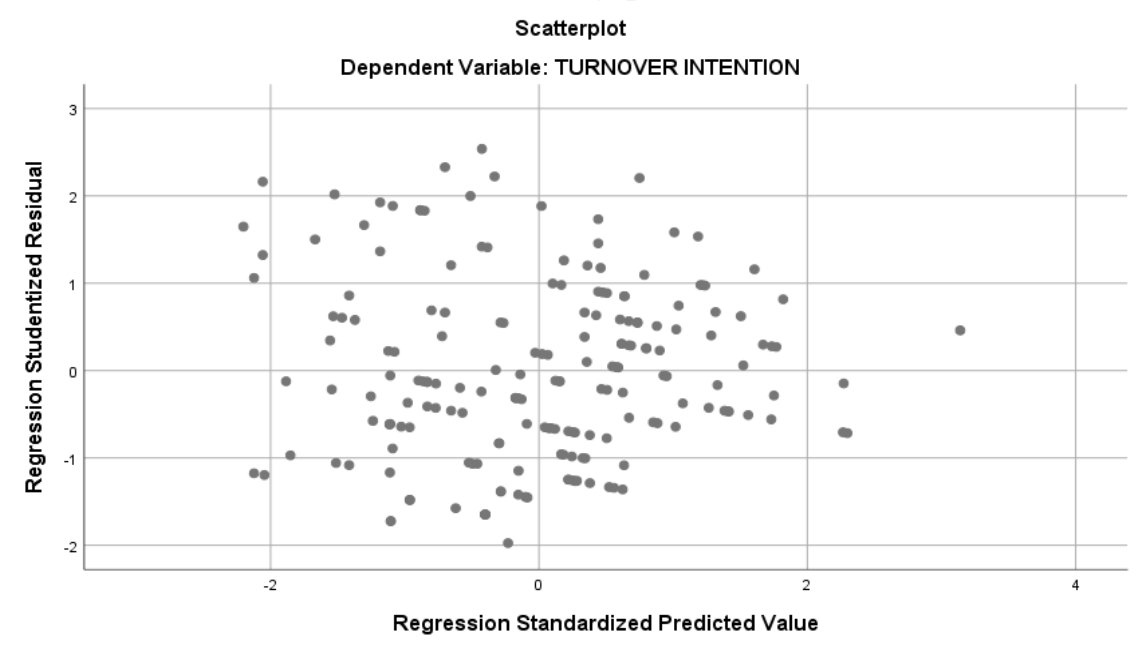

Figure 3. Heteroscedasticity Test Results

\section{Multiple Linear Regression Analysis}

According to multiple linear regression analysis, these regression equation model was obtained:

$\mathrm{Y}=3,467-0,334 \mathrm{X} 1+0,142 \mathrm{X} 2-0,032 \mathrm{X} 3$.

1) These results showed that tvalue from career development variable had t value $(2.558)>t$ table (0.138), with Sig. $0.011<0.05$, so it could be said that career development partially had strong impact over turnover intention.

2) These results showed that $t$ value of workload variable had (1.962)> $t$ table (0.138) with Sig. 0.051>0.05, so it could be concluded that workload had not influence towards turnover intention.

3) The results showed that tvalue of workload variable had (0.703)>t table (0.138) with Sig. $0.483>0.05$, so it could be said that compensation had none affections against turnover intention. 
Table 6. Multiple Linear Regression Analysis

\begin{tabular}{|c|c|c|c|c|c|c|}
\hline \multicolumn{7}{|c|}{ Coefficients $^{a}$} \\
\hline \multirow[b]{2}{*}{ Model } & & \multicolumn{2}{|c|}{ Coefficients } & \multirow{2}{*}{$\begin{array}{c}\text { Coefficients } \\
\text { Beta }\end{array}$} & \multirow[b]{2}{*}{$t$} & \multirow[b]{2}{*}{ Sig. } \\
\hline & & $\mathrm{B}$ & Std. Error & & & \\
\hline 1 & (Constant) & 3.467 & 1.778 & & 8.274 & 0.000 \\
\hline & Career Development & -0.334 & 0.130 & -0.212 & -2.558 & 0.011 \\
\hline & Workload & 0.142 & 0.072 & 0.139 & 1.962 & 0.051 \\
\hline & Compensation & -0.032 & 0.045 & -0.058 & -0.703 & 0.483 \\
\hline
\end{tabular}

a. Dependent Variable: TURNOVER INTENTION

According to simultaneous test results (F Test) its common that Fcount value (4.73) has greater than Ftable (2.65), with that it could be settled that career development, workload and compensation together had influence on turnover intention.

\section{Table 7. F Test Results}

\begin{tabular}{|c|c|c|c|c|c|c|}
\hline \multirow[b]{2}{*}{ Model } & \multicolumn{6}{|c|}{ ANOVA $^{a}$} \\
\hline & & Sum of Squares & df & $\begin{array}{l}\text { Mean } \\
\text { Square }\end{array}$ & $\mathrm{F}$ & Sig. \\
\hline 1 & Regression & 187,374 & 3 & 62,458 & 4,732 & $.003^{b}$ \\
\hline & Residual & 2520,965 & 191 & 13,199 & & \\
\hline & Total & 2708,338 & 194 & & & \\
\hline
\end{tabular}

Those simultaneous effect from three independent variables to dependent variable is $58 \%$.

Table 8. Determination of Coefficient Test Results

\begin{tabular}{|c|c|c|c|c|}
\hline \multicolumn{5}{|c|}{ Model Summary } \\
\hline Model & $\mathrm{R}$ & R Square & $\begin{array}{l}\text { Adjusted } \\
\text { R Square }\end{array}$ & $\begin{array}{l}\text { Std. Error } \\
\text { of the } \\
\text { Estimate }\end{array}$ \\
\hline 1 & $.721 \mathrm{a}$ & 0.510 & 0.580 & 5.395 \\
\hline \multicolumn{5}{|c|}{ a. Predictors: (Constant), Total_X3,Total_X2, Total_X1 } \\
\hline \multicolumn{5}{|c|}{ b. Dependent Variable: Total_Y } \\
\hline
\end{tabular}

\section{CONCLUSION AND SUGGESTIONS}

\section{Conclusion}

From these estimation results and discussion alongside with hypothesis test results it could be drawn several conclusions like in belows:

1) There had huge impact between career development and employee turnover intention at PT. XYZ Area JATA 2. These results was confirmed by Ghafoor, et., Al. (2017) research which states that there had strong negative impact towards career development on turnover intention. 
2) There had no influence between workload and employee turnover intention at PT. XYZ Area JATA 2. These results was confirmed by Aristawati (2019) research which said that there had none reaction between workload to turnover intention.

3) There had none reaction from compensation to employee turnover intention at PT. XYZ Area JATA 2. These result was contrary to research conducted by Kumbara (2018) which argued that compensation had negative influence over turnover intention.

4) There had simultaneous reactions between those variables from Career Development, Workload and Compensation against Turnover Intention at PT. XYZ Area JATA 2.

\section{Suggestions}

From several results from these research, authors could provide some of suggestion as in following belows:

1) Author suggested that companies should provide opportunities for career development which open to every employees and periodically review employees who exceel by considering length of work at company. Especially for workers with Collection \& Recovery Field and UFI Marketing Field positions who has largest portion of employees at PT. XYZ. By Providing opportunities to enhance their career, training, education and job placement according to their interests and expertise that its expected to reduce these turnover intention at PT. XYZ employees.

2) Author advised about work shifts that needs to change the system so employees would feel that system which applied in according to rules and policies at PT. XYZ, especially in Billing Department, which works from morning to night (without work shifts), so employees felt that they working for more than applied policies. Therefore, specifically for Billing Department, those work shifts should be added and implemented at company.

3) Author give suggestion to PT. XYZ Area JATA 2 to recounted these compensation given to employees should according to their workloads and also from their performance which exceel the targets alongside with length of career, they have chance to get better position at this company. Especially for employees who work at Collection \& Recovery Field Position and UFI Marketing Field which has largest portion of employees field at this company.

4) For next further researcher it is expected to add other variables who has strong influence to evaluating these turnover intention beside these variables studied which is career development, workload and compensation.

\section{REFERENCES}

Aristawati, N. (2019). Pengaruh Beban Kerja, Lingkungan Kerja, dan Gaya Kepemimpinan Demokratis terhadap Turnover Intention Karyawan Produksi pada PT Gaya Remaja Industri Indonesia. Thesis. UIN Sunan Ampel Surabaya.

Ghafoor, S., et., al. (2017). The Effect of Financial Compensation and Perceived Career Progression on Employee Turnover Intentions with Self Actualization as a Mediator. Governance and Management Review, 2(1):61-84. 
Kumbara, V. B. (2018). Pengaruh Kepuasan Kerja, Kompensasi, dan pengembangan Karir Terhadap Turnover Intention Karyawan Bank Syariah Mandiri Cabang Padang. Jurnal EKOBISTEK Fakultas Ekonomi, 7(1):43-50.

Mahdi A. F., et., al. (2012). The Relationship between Job Satisfaction and Turnover Intention. American Journal of Applied Sciences, (9):1518-1526.

Runkat, A. J., \& Aulia, I. N. (2019). The Influence of Motivation, Leadership Style, and Compensation on Organizational Commitments at PT. Dharma Guna Wibawa. International Journal of Innovative Science and Research Technology, 4(7):675-680.

Sunyoto, D. (2012). Manajemen Sumber Daya Manusia. Yogyakarta: Center for Academic Publishing Service. 